\title{
ANALYSIS AND DESIGN OF APPLICATION OF SALES AND CONTROL OF STOCK OF DAILY GOODS WITH ROP (REORDER POINT) METHOD
}

\author{
Annisak Izzaty Jamhur ${ }^{1}$, Novi Trisna ${ }^{2}$, Yesri Elva ${ }^{3}$ \\ Universitas Putra Indonesia "YPTK" Padang 123 \\ annisakizzaty@gmail.com¹, novi_trisna@upiyptk.ac.id², yesri_elva@upiyptk.ac.id ${ }^{3}$
}

\begin{abstract}
In the era of globalization now developments in the field of information technology are increasingly rapid. No wonder now more and more shops are starting to develop their administrative systems using information technology and one of them is a shop in the field of daily goods. Some stores use various ways to attract as many customers as possible. So that the data processing is slow and shop owners often have difficulty in finding data that has been processed. To provide satisfactory services for customers, it is necessary to reform several systems, including information systems for sales, purchasing, making daily, monthly, annual sales reports, and inventory data reports using the ROP (Reorder Point) method and designing using the ASI model (System Analysis Information), while the process of making a desktop program or application uses the VISUAL BASIC.NET 2010 programming language that is supported by the MySQL database.
\end{abstract}

Keywords : Analysis and Design, Sales, Stock, ROP, Visual Basic.Net 2010, Inventory.

\section{INTRODUCTION}

The rapid development of science and technology today, especially computerbased information technology is felt to be instrumental in various aspects of life because computer is one human aid used in the process of data processing, in the field of business, education, health, government agencies, private and other businesses because it can help in terms of improving quality, speed, practicality, and ease in the field of information. (Kiki Rizki Maulana and Bunyamin, 2015)

Haikal Shop is a wholesaler and retail that sells daily items such as sugar, cooking oil, wheat, eggs, coffee, tea, snacks, Miuman, and many more. The management of the sales data in this store is still conventionally done, documentation of data such as sales are still recorded manually and counting using calculators and stock items that sometimes do not exist at all. Where the Haikal shop serves as the cashier is the owner of the shop.

With the design of a desktop-based inventory information system application, the cashier can manage and search for data items quickly and can provide accurate information to the head of the store owner. To overcome errors in counting the number of items. To know the inventory report in the warehouse effectively. To find out the advantages in selling goods(Budiman \& Mulyani, 2016).

\section{LITERATURE REVIEW System Definitions}

According to Sutabri (2012:38) Information System is a system in an organization that brings together the need for daily transaction processing that supports the function of operations of a managerial organization with the strategy activities of an organization to be able to provide the necessary reports.

\section{Inventory Definition}

Inventory is a smooth activity that exists in a company, if the company is a trading company then the supply is interpreted as goods stored for sale in the normal 
operation of the company, whereas if the company is a manufacturing company then the supply is interpreted as the raw material contained in the production process or stored for purpose of the production process. (Solihin \& Nusa, 2017)

\section{ROP (Reorder Point)}

Reorder Point is one of the methods of inventory management in which this method helps its users when it comes to ordering the inventory again.

According to Irwadi, Maulan the amount of supplies that must remain at the time the booking is made called the point of the message back and at the level of booking must be done so that the goods come in time.

As for the ROP formula as follows:

$$
\mathrm{ROP}=\mathrm{Lt} \times \mathrm{Q}
$$

Description:

$$
\begin{array}{ll}
\text { ROP } & =\text { Reorder Point } \\
\text { Q } & =\text { Average usage (day, week, or month) } \\
\text { Lt } & =\text { Lead Time (day, week, or month) }
\end{array}
$$

Here are some advantages of using the Reorder Point (Irwadi, 2015) method:

1. Guaranteed material availability due to the amount of stock supply Always refills before the stock is depleted.

2. The number of consumer requests for goods ordered can be fulfilled upon request.

3. The frequency of booking becomes scheduled because of the order of goods to the agent Following the target that has been estimated due to adequate goods demand.

Reorder Point (ROP) is the level of inventory where re-booking must be made. The inventory Model adopts that a company will wait until its level reaches zero before the company reordering and instantaneously ordered shipments will be accepted. The time between the booking or delivery time can be fast or slow, so it is necessary to set the booking method again. If ROP is late it will result in the cost of lack of material (stock out cost) and if ROP is too quick to eat, there is an additional cost (extra carrying cost). (Lukmana \& Trivena, 2015).

\section{Safety Stock}

According to Lukmana and Trivena (2015), Safety Stock is Inventory To protect or safeguard the additional Lack of material (stock out). Some factors that determine the amount of inventory safeguards are:

1. Average raw material use.

2. Time factor.

3. Fees used.

Standard quantity

1. Minimum inventory.

2. The size of the standard order.

3. Maximum inventory.

4. Return order level.

5. Administration of supplies.

Making it easier for customers to find new products for them and avoid Purchase to another company.

\section{RESEARCH METHODS}


The research methodology following the stage/framework that will be passed in this research can be seen in Figure 3.1:

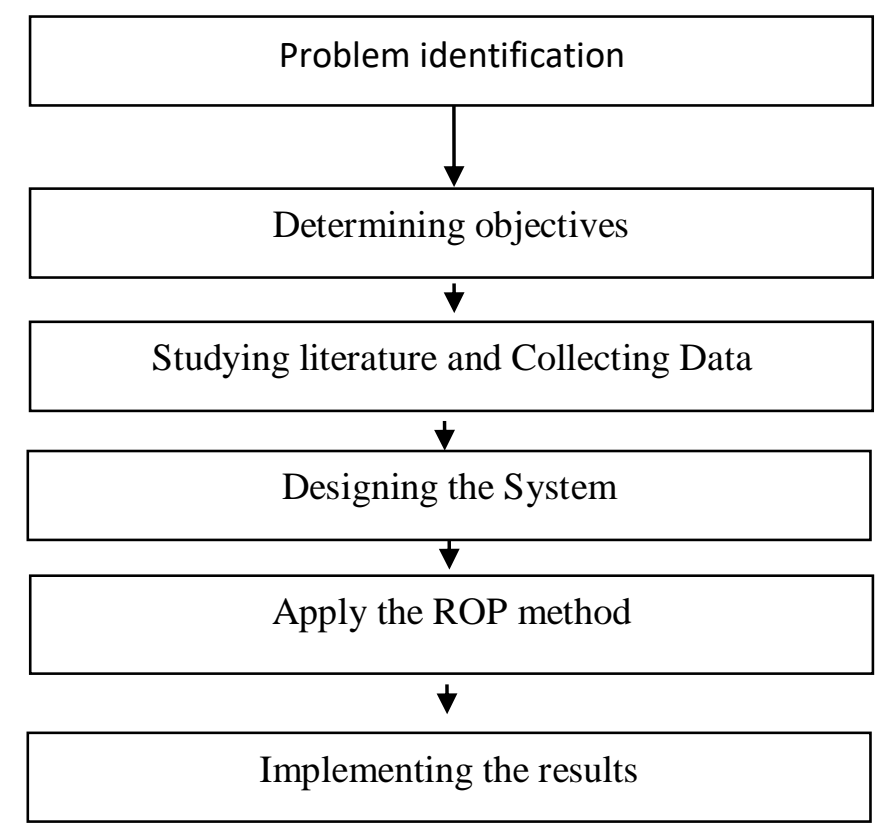

Figure 1. Research frameworks

\section{RESULTS AND DISCUSSIONS \\ Evaluation Of The Current System}

Based on the explanation of the ongoing system and analysis that has been done in the Haikal store, then there are several weaknesses found in the current system, including:

1. In performing the calculation process of the purchase transaction and the sales transaction still using the calculator as a tool, so that it often occurs a miscalculation and raises doubts In obtaining the final result for the report.

2. Difficulty in detecting the amount of stock/inventory of goods.

3. The data storage is done manually that is written on the book and paper or in other words, does not use the database, so it takes a relatively long time and vulnerable to the occurrence of data harvesting by irresponsible parties.

4. In conducting the creation of the report is still done manually that is written hand on the book or paper, so it takes a relatively long time and the risk of scattered or loss is considerable.

5. Shop owners have difficulty in sudden decision making

\section{New Information Stream (ASI)}

This new information system design tool aims to facilitate an understanding of existing systems or systems to be established, where the information system flow (ASI) is a chart showing the overall work of the system. This chart describes the sequences of the procedures in the system indicating what is being done on the system. For more details, the new information system flow on the new Haikal store can be seen in Figure 2. below: 


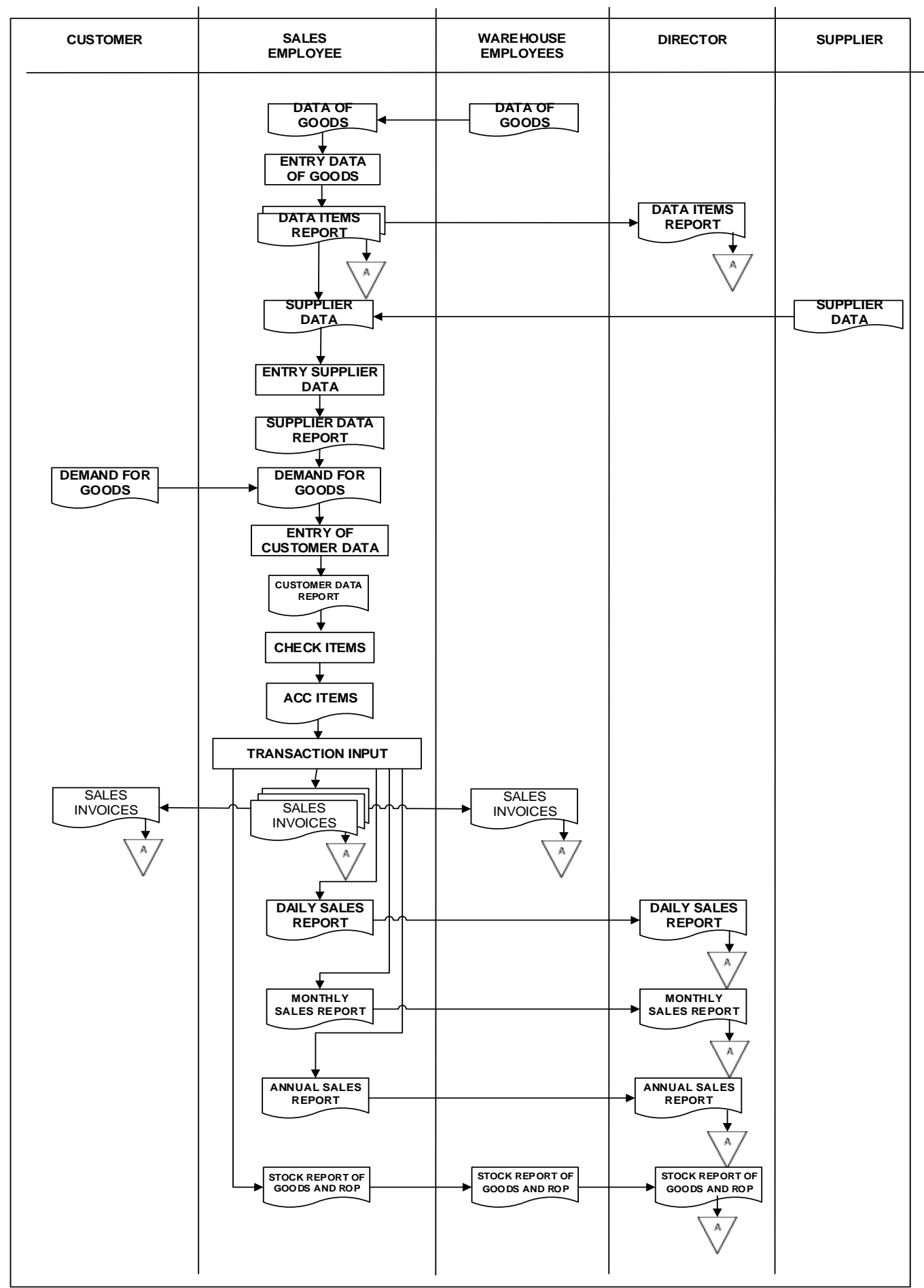

Figure 2. Flow Diagram Information System (ASI) New Haikal Shop

\section{Context Diagram}

Context Diagram is a description of a system contained in an organization that shows the boundary of the system, the interaction between external entities with a system and information generally flows between the entity and the system. To clarify the scope of writing, it needs to be spelled out the Context Diagram in Figure 3. below : 


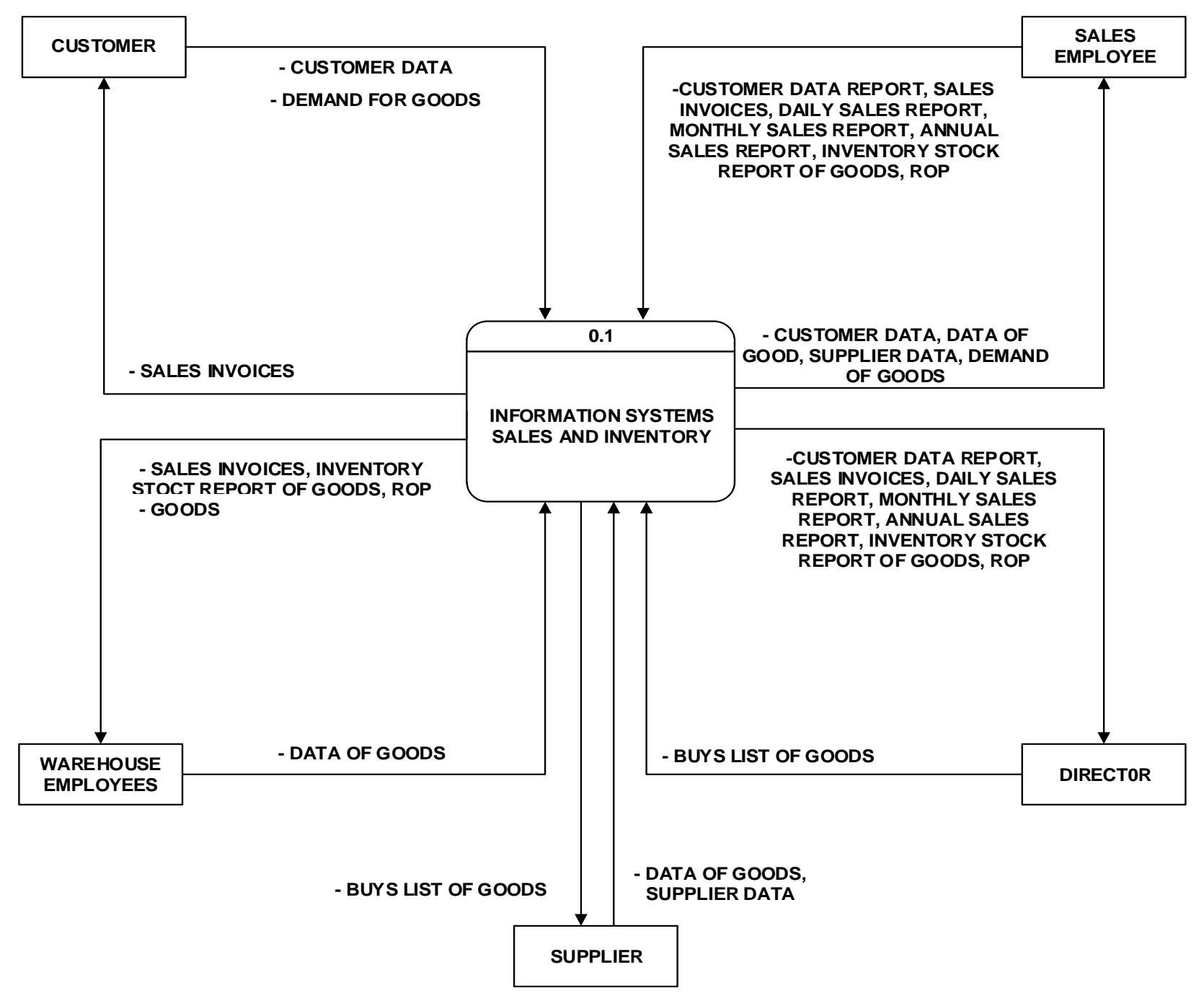

Figure 3. Haikal Store Context Diagram

\section{System implementation}

On the input data of goods, which are incubation in the form of item code, item name, unit, buy price, selling price, and stock. More details can be seen in figure 4. below. 


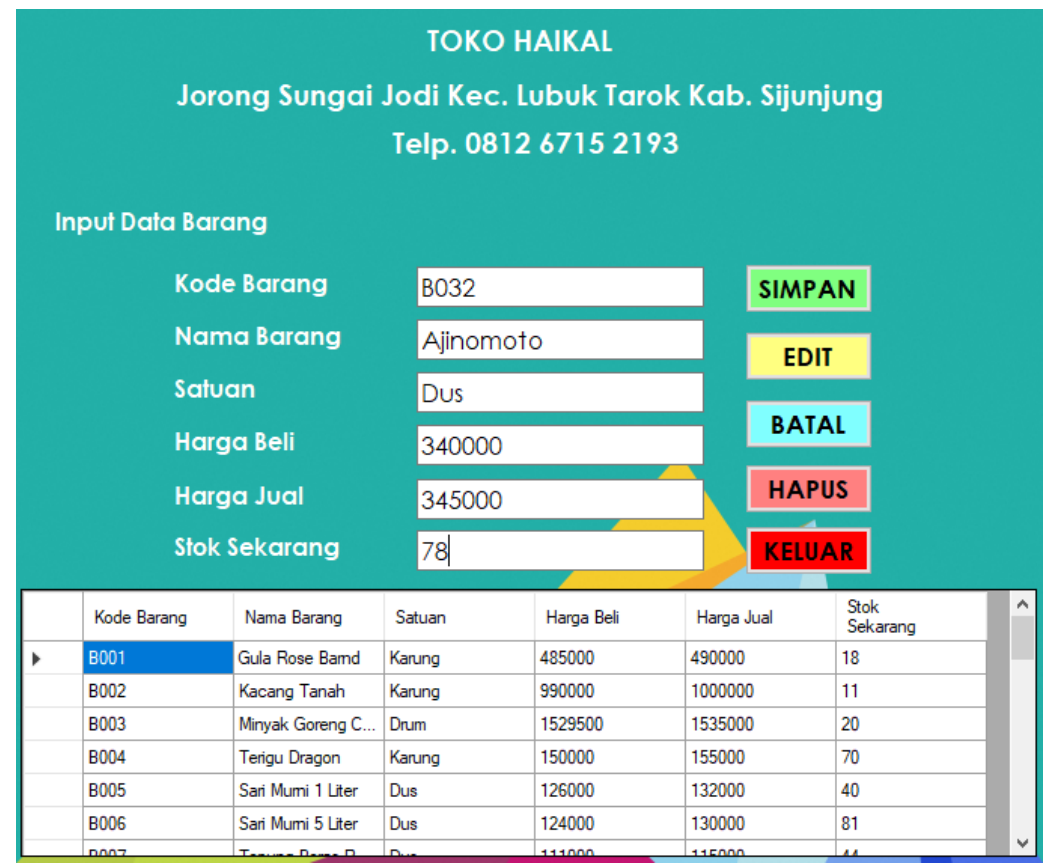

Figure 4. Input Item Data display

In the ROP analysis view, data incubation includes ROP code, item code, item name, lead time, need, and safety stock. For more details can be seen in Figure 5. below.

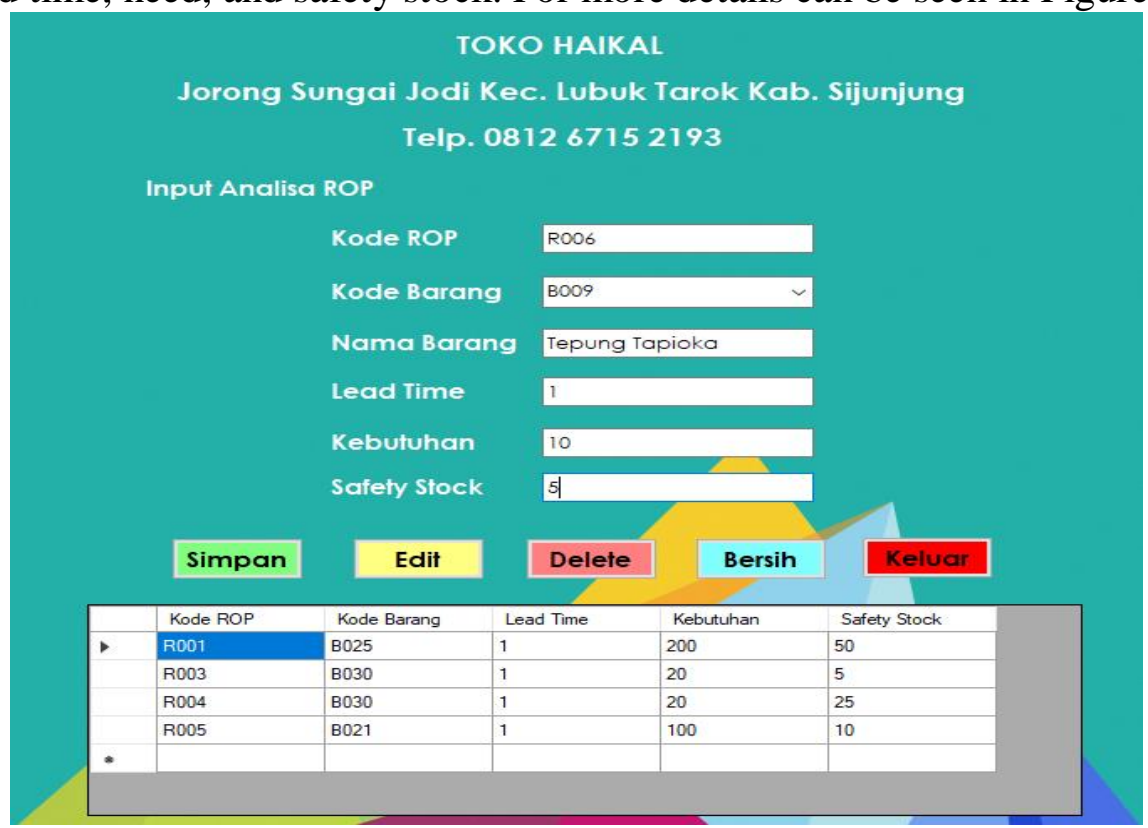

Figure 5. ROP Analysis View

The ROP Analysis report is a report containing information about the Reorder Point (ROP) data that can be accessed by admins and leaders. More details can be seen in Figure 6. below. 


\section{TOKO HAIKAL}

Jorong Sungai Jodi, Kec. Lubuk Tarok Kab. Sijunjung

Telp. 081267152193

LAPORAN ANALISA ROP

\begin{tabular}{|c|c|c|c|c|c|}
\hline NO & Kode ROP & Kode Barang & Nama Barang & ROP & Keterangan \\
\hline 1 & R001 & B025 & Capuccino Mallo & 250 & Barang Aman \\
2 & R003 & B030 & Borobudur & 25 & Perlu Order Barang \\
3 & R004 & B030 & Borobudur & 45 & Perlu Order Barang \\
4 & R005 & B021 & Rajaku & 110 & Barang Aman \\
\hline \multicolumn{4}{|r}{} \\
\hline
\end{tabular}

Nofrinal

Figure 6. ROP Analysis Report View

\section{CONCLUSION}

a. The presence of sales applications with the ROP (Reorder Point) method using the programming language VB.NET 2010 and MySQL Database can help Haikal store in improving service to customers.

b. With the presence of sales application with the ROP (Reorder Point) method using VB.NET 2010 programming language and MySQL Database can help Haikal store in managing sales data quickly and efficiently.

c. With the application of stock control of goods daily with the ROP method (Reorder Point) using the programming language VB.NET 2010 and MySQL Database can help the Haikal shop owners in the search for goods data quickly and accurately and can reduce the cost and time in recording data.

d. With the application of stock control of goods daily with the ROP method (Reorder Point) using the programming language VB.NET, 2010 and MySQL Database can be useful in controlling the stock of goods in the Haikal store.

\section{References}

Maulana, K. R. \& Bunyamin. (2015). Rancang Bangun Sistem Informasi Penjualan dan Stok Barang Di Toko Widari Garut. Journal Algoritma 12(1)

Sutabri, T . (2012). Analisis Sistem Iinformasi. Yogyakarta. Andi.

Solihin, H. H. \& Nusa, A. A. F. (2017). Rancang Bangun Sistem Informasi Penjualan, Pembelian Dan Persediaan Suku Cadang Pada Bengkel Tiga Putra Motor Garut. Journal Infotronik 2(2)

Irwandi M. (2015). Penerapan Reorder Point untuk Persediaan Barang Baku Produksi Alat Pabrik Kelapa Sawit Pada PT. Swakarya Adhi Usaha Kabupaten Banyuasin. Journal ACSY. 2(1)

Lukmana, T. \& Trivena, D. (2015). Penerapan Metode EOQ dan ROP (Studi Kasus: PD. BARU). Journal Jutisi 1(3). 
Budiman, A., \& Mulyani, A. (2016). RANCANG BANGUN APLIKASI SISTEM INFORMASI PERSEDIAN BARANG DI TB. INDAH JAYA BERBASIS DESKTOP. Jurnal Algoritma, 13(2), 374-378.

https://doi.org/10.33364/algoritma/v.13-2.374 